\title{
ANALISIS KORELASIONAL FINANCIAL ATTITUDE, FINANCIAL KNOWLEDGE DAN SPIRITUAL INTELLIGENCE PADA MAHASISWA PASCASARJANA
}

\author{
Andi Amri**, Tri Widyastuti ${ }^{2}$, Syamsul Bahri ${ }^{3}$ \\ ${ }^{123}$ Magister Manajemen Sekolah Pascasarjana, Universitas Pancasila, Jakarta \\ andiamri43@gmail.com ${ }^{1,}$ triewidhiastuti@yahoo.com ${ }^{2}$, syamsul76@gmail.com³
}

\begin{abstract}
This study aims to describe identify the relationship between financial attitude, financial knowledge, and spiritual intelligence of postgraduate students. This research is a descriptive and correlational study with a sample of 391 postgraduate students studying at state universities (PTN) in the province of DKI Jakarta. The sampling technique used purposive sampling technique. The analysis technique used is the Pearson correlation test using the SPSS program. This study reveals that there is a significant relationship between financial attitude and financial knowledge. In addition, there is also a significant and positive relationship between financial knowledge and spiritual intelligence. Meanwhile, the analysis between financial attitude and spiritual intelligence does not show a significant relationship, so it can be concluded that there is no relationship at all.
\end{abstract}

Keywords: Financial Attitude, Financial Knowledge, Spiritual Intelligence, Postgraduate

\begin{abstract}
ABSTRAK
Penelitian ini bertujuan mengidentifikasi hubungan financial attitude, financial knowledge, dan spiritual intelligence mahasiswa pascasarjana. Penelitian ini merupakan penelitian deskriptif dan korelasional dengan sampel sebanyak 391 mahasiswa pascasarjana yang kuliah di perguruan tinggi negeri (PTN) di provinsi DKI Jakarta. Teknik sampling menggunakan purposive sampling techinque. Teknik analisis yang digunakan adalah uji korelasi pearson dengan menggunakan bantuan program SPSS. Penelitian ini mengungkapkan bahwasanya terdapat hubungan yang signifikan antara financial attitude dengan financial knowledge. Selain itu, terdapat hubungan yang signifikan dan positif juga pada financial knowledge dengan spiritual intelligence. Sedangkan untuk analisis antara financial attitude dan spiritual intelligence tidak menunjukkan hubungan yang signifikan, sehingga bisa disimpulkan tidak ada hubungan sama sekali.
\end{abstract}

Kata Kunci: Financial Attitude, Financial Knowledge, Spiritual Intelligence, Pascasarjana

\footnotetext{
**Penulis Korespondensi
} 


\section{PENDAHULUAN}

Perkembangan zaman telah mempengaruhi segala aktivitas masyarakat Indonesia. Aktivitas ini membuat masyarakat Indonesia semakin rendah dalam mengelola keuangan yang mereka miliki. Kadang kala dalam membeli barang ataupun terkait dengan penggunaan uang lebih tertuju kepada keinginan ketimbang kebutuhan. Maka tidak salah jika Geotimes dalam Asih \& Khafid (2020) dalam riset LIPI menyatakan bahwa masyarakat Indonesia menduduki peringkat ketiga dari 106 negara yang dijadikan sampel. Sampel disini terkait dengan tingkat perilaku konsumerisme yang tinggi pada masyarakat Indonesia. Sebagian besar masyarakat sebenarnya membeli berbagai jenis produk-produk yang muaranya tertuju pada toko sekitar $74 \%$. Padahal keputusan tersebut belum dipikirkan terlebih dahulu secara matang. Keputusan pembelian tersebut biasanya bukan didasarkan pada kebutuhan, namun karena keinginan terhadap produk atau merek tertentu (Triwidisari \& Ahmad, 2017).

Padahal dalam mengelola keuangan ada konsep kunci yang harus sama-sama kita ketahui. Menurut Karyanto dalam Finance.detik.com (2020), konsep kunci tersebut meliputi kemampuan dalam membagi porsi sesuai anggaran dan prioritas, rumus pembagian tiga jurus anggaran ini adalah 50-30-20. Secara detail maksud dari pembagian tersebut yaitu, 50\% untuk pengeluaran wajib dan fleksibel, $30 \%$ untuk untuk tabungan, dan $20 \%$ buat kebutuhan yang berbau kesenangan pribadi dan keluarga yang meliputi hiburan, belanja atau biaya wisata. Karena semua pembagian tersebut sudah lumrah terjadi di dalam kehidupan manusia. Kalau tidak diatur, tentu akan berpengaruh terhadap keberlangsungan akan uang yang dimiliki. Namun belum semua masyarakat Indonesia yang paham akan itu.

Dalam penelitian ini, penulis ingin melihat hubungan dari financial attitude, financial knowledge, dan spiritual intelligence. Mungkin ada hubungan yang terjadi diantara tiga variabel ini, sehingga dapat memperkuat landasan dari penelitian LIPI terkait budaya behavioral finance masyarakat Indonesia. Variabel pertama adalah financial attitude atau biasa dikenal dengan sikap keuangan. Banyak para ahli mendefinisikan hal ini. Namun menurut beberapa para ahli seperti Sunyoto (2013), Humaira, I., \& Sagoro (2018), Pradiningtyas \& Lukiastuti (2019) dan Aminatuzzahra (2014), sikap sebagai suatu yang tertuju pada bagaimana seseorang untuk dapat mengendalikan emosi, perbuatannya, ucapannya, bahkan tindakannya dalam berkehidupan sehari-hari. Sementara secara defenisi, sikap keuangan adalah suatu bentuk pola pikir yang lahir dari adanya pendapat dan evaluasi mengenai keuangan seseorang (Pankow, 2003). Berbagai ahli banyak mengungkapkan dimensi-dimensi yang terdapat didalamnya. Penulis melihat, dimensi yang dikemukakakn oleh Yamauchi, K.T, Templer (1982) lebih tepat sasaran. Dimana beliau membagi menjadi lima dimensi. Lima dimensi tersebut adalah power-prestige, retention time, distrust, quality, dan anxiety. Peneliti berasumsi, sikap keuangan yang baik tentu akan membantu seseorang untuk paham dan percaya, bahwasanya dirinya memiliki hubungan dengan uang yang ada.

Peneliti sebelum melakukan penelitian mendalam juga sudah melakukan penelitian sederhana pada tanggal 1 Maret 2021 sampai 5 Maret 2021 kepada mahasiswa pascasarjana melalui wawancara online yang berlangsung selama 20-30 menit per responden terkait dengan 
sikap keuangan. Dari 8 orang responden menjawab sangat beragam. Ada yang menyatakan sikap keuangan itu terkait dengan cara individu mengkondisikan kebutuhan yang ada saat ini sebaik mungkin, terorganisir dan teratur; sikap seseorang yang boros atau hemat; sikap keuangan yang terlihat dari ketertarikannya untuk berinvestasi, apakah itu melalui saham, emas dan lain sebagainya. Sikap keuangan juga bisa dilihat dari kemampuan dalam memanajemen keuangan (Rahmayanti et al., 2019). Kemampuan mengalokasikan pengeluaran dan pendapatan dan terakhir sikap keuangan yang dilihat dari kecendrungan menggunakan sumber keuangan. Misalnya ketika seseorang menganggap bahwa uang itu penting, maka dalam pikirannya akan muncul persepsi bahwa dengan uang bisa melakukan sesuatu. Sikap juga mungkin mempengaruhi dalam menentukan sebuah keputusan. Inilah jawaban dari semua responden yang penulis wawancarai. Inilah wawancara semi terstruktur yang peneliti dapatkan.

Kemudian financial knowledge juga variabel penting dalam penelitian ini. Financial knowledge ialah bagian yang tidak bisa dipisahkan dan bisa disebut paling penting bagi seseorang untuk dapat membuat keputusan keuangan yang tepat. Keputusan keuangan itu akan menghasilkan perencanaan keuangan masa depan yang baik. Semakin baik pemahaman akan pengetahuan keuangannya, maka perencanaan kehidupan juga semakin baik. Sementara ketidaktahuan akan konsep dasar keuangan maka juga memiliki hubungan sinkronisasi dengan rendahnya akan perencanaan keuangan dan investasinya (Rasuma Putri \& Rahyuda, 2017; Akmal \& Saputra, 2016; Rasyid, 2012). Peneliti juga melakukan wawancara yang sama terkait dengan pengetahuan keuangan ini. Ternyata masih banyak yang belum paham dan mengerti, dari 8 responden hanya 2 responden (TB dan $\mathrm{PP}$ ) yang mampu menjelaskan dengan baik pemahaman akan pengetahuan keuangan. Rata-rata jawaban responden hanya terkait pemasukan dan pengeluaran uang serta informasi penting dalam memanfaatkan uang. Namun secara spesifik masih belum. Hal ini juga ditandai dengan ketidakmampuan responden untuk mencatat pengeluaran dan pemasukan secara tertulis. Kebanyakan masih abai dan mereka berpikir tidak terlalu penting. Adapun yang masih berpikir untuk mencatat pengeluaran maupun pemasukan itu hanya terlintas dikepala saja.

Variabel selanjutnya adalah spiritual intelligence yang tentu variabel ini tidak akan terlepas dengan agama yang mereka yakini. Agama mungkin secara vertikal terkait dengan hubungan dirinya dengan Tuhannya. Namun dibalik itu, diyakini juga memiliki hubungan agama dengan implementasi kehidupannya sehari-hari. Seperti yang telah penulis lakukan, berdasarkan hasil wawancara, dimana pertanyaan terkait tanggapan responden tentang orang yang memiliki kecerdasan spiritual yang patuh terhadap ajaran agama dan selalu berdoa memiliki pengelolaan keuangan yang baik. Penulis menyimpulkan responden setuju dengan tanggapan tersebut ada 4 responden. Mereka berkeyakinan, setiap orang yang telah menjalani agamanya dengan baik dan menjalani semua yang diperintah oleh Tuhannya serta menjauhi semua laranganya pasti memiliki tingkat pengelolaan yang baik. Apapun itu agamanya, pasti sudah diajarkan. Apalagi dalam agama islam diajarkan untuk menabung dan tidak berbuat boros dan berprilaku mubazir. Salah satunya terdapat dalam surat Al Isra ayat 26-27, Allah SWT menyebutkan orang yang menghamburkan harta merupakan saudaranya setan. Jadi sudah pasti 
orang yang beriman akan menjalani sesuai ketentuan-Nya. Sementara 5 responden (TB, YD, HM, dan PP) menyatakan tidak setuju. Tidak selalu orang yang beragama dan menjalani syariatNya memiliki tingkat pengelolaan keuangan yang baik. Karena setiap orang memiliki karakter dan budaya yang berbeda. Hal ini tentu menjadi unsur psikologis tersendiri yang memiliki berbagai opini yang mendalam.

Kecerdasan spiritual biasa dikenal dengan kecerdasan jiwa. Orang yang memiliki kecerdasan akan jiwa yang baik, senantiasa akan membangun jati dirinya secara utuh, memiliki pemaknaan mendalam, mengandung nilai-nilai dan tujuan hidup yang jelas dan tepat sasaran. Kecerdasan spiritual lahir tidak hanya lahir dari nilai-nilai yang dianut oleh orang lain ataupun pemahaman yang diberikan seseorang. Namun juga lahir dari penciptaan akan asumsi-asumsi nilai-nilai dan tujuan yang ada dalam diri seseorang (Sunar, 2010; Chotimah, 2015). Nilai-nilai dan tujuan diri seseorang ini, akan memiliki makna yang mendalam. Makna tersebut menjadi penentu identitas seseorang dan berpengaruh sangat signifikan. Orang yang memiliki kecerdasan spiritual yang baik, akan mampu menemukan sisi pemaknaan terbaik yang ada dalam hidupnya.

Inilah variabel yang akan dilihat hubungan korelasional (Hidayat, 2020; Ramadhan, 2019). Supaya penelitian ini tidak terlalu umum, maka peneliti mengambil cakupan mahasiswa. Karena mahasiswa dipandang sebagai generasi berpendidikan yang merupakan bagian dari masyarakat dan jumlahnya juga cukup besar. Selain itu, mahasiswa adalah agent of change turun berperan dalam membawa perubahaan segala bidang termasuk dalam hal perekonomian. Oleh karena itu, cakupan penelitian ini dikhususkan kepada mahasiswa Pascasarjana yang terdapat di perguruan tinggi negeri yang ada di provinsi DKI Jakarta. Sehingga nantinya dalam penelitian ini diharapkan peneliti dapat mencapai tujuan penelitian yaitu mengidentifikasi hubungan financial attitude, financial knowledge, dan spiritual intelligence mahasiswa pascasarjana. Sehingga penulis memberikan judul artikel ini: Analisis Korelasional Financial Attitude, Financial Knowledge, dan Spiritual Intelligence Mahasiswa Pascasarjana.

\section{LITERATUR REVIEW}

Financial attitude merupakan pembahasan yang sangat populer dizaman sekarang. Karena financial attitude adalah bagian dari behavioral finance dan merupakan rumpun ilmu dari keuangan era baru. Sehingga sangat banyak peneliti yang mendefenisikan pengertian dari sikap keuangan ini. Seperti yang dikemukakan oleh Rajna \& Moshiri (2011) yang menjadi point utama sikap keuangan adalah lahir dari adanya pikiran seseorang, opini atau pendapat, serta penilian terhadap uang dan dikaitkan dengan sikapnya. Sementara pendapat lain dikemukakan oleh Furham (1984), dimana beliau mengungkapan ada enam konsep penting dalam sikap keuangan, yaitu obsession terkait pemikiran dan persepsi, power dianggap pengendalian dan solusi, effort terkait kepantasan, inadequacy terkait kekurangan, retention, dan security terkait dengan cara pandang. Jadi dapat peneliti simpulkan bahwasanya ada tiga komponen penting yang saling berkaitan dalam sikap keuangan, yaitu komponen kognitif, afektif, dan perilaku. Komponen kognitif tercerminan dari pikiran dan kepercayaan yang didasarkan pada informasi 
yang saling berkesinambungan dengan objek. Komponen afektif terlihat dari dimensi emosi akan sikap terhadap objek, dan terakhir komponen perilaku terlihat dari tindakan terhadap objek secara predisposisi.

Financial knowledge adalah suatu kondisi dimana seseorang dalam mengambil keputusan dengan memasukan unsur sumber daya, keterampilan dan pengetahuan konseptual dalam memanajemen informasi untuk menentukan keputusan investasi dan keuangan yang tepat berdasarkan berbagai kombinasi tersebut (Muson, 2000). Menurut Chan \& Volpe (1998) dalam Astuti, (2019), pengetahuan keuangan memuat akan dimensi pengetahuan dasar terkait dengan uang pribadi, manajemen uang, tabungan dan investasi, manajemen kredit dan utang. Pengetahuan keuangan tidak terlepas dari namanya pemahaman dan konsep keuangan serta kemampuan dalam memilih strategi yang tepat untuk memgambil suatu tindakan dan keputusan (Hogarth, 2002). Pengetahuan keuangan tidak terlepas dari fenomena psikologi pribadi yang dimiliki seseorang. Ketika seseorang memiliki uang, tentu secara psikologinya sudah berpikir uang itu akan digunakan untuk apa dan dimanfaatkan bagaimana. Ini tercermin ketika sudah memiliki pengetahuan yang mendalam (Astuti, 2019). Oleh karena itu, penulis menimbang bahwasanya financial knowledge adalah pemahaman mendalam seorang individu untuk dapat mengambil keputusan yang tepat dan bijak yang iddasari akan pengetahuan dasar tentang keuangan, manajemen utang, tabungan dan investasi.

Selanjutnya Spiritual Intelligence, adalah kecerdasan yang timbul dan terbentuk dari nilai-nilai, pemahaman, pemaknaan, dan tujuan yang komprehensif. Kecerdasan spiritual sesuatu yang cukup baru dalam keilmuan keuangan. Karena sangat jarang yang mengkaitkan dua variabel sebelumnya dengan kecerdasan spiritual ini. Sehingga kecerdasan spiritual ini akan menjadi ilmu baru dalam membangun manusia menjadi pribadi manusia seutuhnya, berkarakter dan berwawasan (Pasek, 2016). Sina (2012) mengungkapkan ada indikator-indikator pembentuk ketika seseorang memiliki kecerdasan spiritual. Indikator tersebut meliputi selalu berdoa kepada yang Tuhannya, tidak mudah menyerah, penuh semangat dan berkemajuan, bersikap terbuka, menuikmati hidup dengan tenang dan berkesinambungan dan terakhir mengelola keuangan berdasarkan ajaran-ajaran agama yang mereka anut dan yakini. Sehingga penulis menyimpulkan, kecerdasan spiritual adalah bagian penting yang harus ada dalam setiap orang. Dialah pembentuk karakter dan jiti diri seseorang untuk menjadi manusia yang lebih baik lagi.

\section{METODE}

Studi ini menggunakan desain korelasional yang bertujuan untuk melihat apakah suatu variabel yang diujikan mempunyai hubungan dengan variabel lainnya atau tidak. Penggunaan desain ini mengacu kepada model penelitian sejenis yang dilakukan oleh Ramdani (2018) dan Suharsimi (2010), dimana hasil penelitian diharapkan dapat menjawab apakah terdapat hubungan antara variabel dan berapa besaran hubungan tersebut. Peneliti menyebarkan kuesioner secara online melalui google form terhadap sejumlah subjek yang dipilih dengan 
menggunakan purposive sampling techinque, yaitu mereka yang berstatus sebagai mahasiswa pascasarjana di wilayah PTN di Provinsi DKI Jakarta.

Terdapat tiga variabel yang diujikan dalam studi ini, yaitu financial attitude, financial knowledge dan spiritual intelligence. Instrument yang digunakan adalah pernyataan berupa skala likert dengan pilihan jawaban mulai dari sangat tidak setuju (poin1) sampai jawaban sangat setuju (poin 5) (Sugiyono, 2017). Teknik analisis yang digunakan adalah uji korelasi pearson dengan menggunakan bantuan program SPSS.

Instrumen yang pertama yaitu Financial Attitude (FA). Teori yang digunakan mengacu kepada Yamauchi, K.T, Templer (1982), jumlah item sebanyak 18 pernyataan dengan 5 dimensi, yaitu Power-prestige, Retention Time, Distrust, Quality, dan Anxiety. Setelah dilakukan uji coba, hasil uji reliabilitas 0,762 artinya reliabel dan uji beda menghasilkan 3 pernyataan yang gugur, sehingga jumlah item akhir 15 pernyataan. Untuk instrument kedua yaitu Financial Knowledge (FK) dengan menggunakan teori yabg dikemukakan oleh Chen, H. \& Volpe (1998). Jumlah item awal 32 pernyataan dengan 10 dimensi, yaitu Pengetahuan Umum Keuangan, Financial Planning, Saving, Spending, Investasi, Asset Liquid, Asset Money, Asset Gold, Borrowing, danAsuransi. Setelah dilakukan uji coba penelitian, hasil uji reliabilitas 0,850 artinya reliabel dan uji beda menghasilkan 3 pernyataan yang gugur, sehingga jumlah item akhir 29 pernyataan. Terakhir instrument yang ketiga yaitu Spiritual Intelligence (SI) teori yang digunakan Zohar, D., \& Marshall (2007). Jumlah item sebanyak 12 pernyataan dengan 7 dimensi, yaitu Memiliki Kesadaran Diri, Memiliki Visi, Bersikap Fleksibel, Berpandangan Holistik, Melakukan Perubahan, Sumber Inspirasi, dan Refleksi Diri. Setelah dilakukan uji coba, hasil uji reliabilitas 0,934 artinya reliabel dan uji beda tetap mempertahankan pernyataan yang ada.

\section{HASIL DAN PEMBAHASAN \\ Hasil}

Penelitian dilakukan Rabu, 17 Maret 2021 sampai Sabtu, 17 Apri 2021 (1 bulan) dan didapatkan responden sebanyak 404 lalu dilakukan seleksi terhadap data yang jelek (outlier) dengan melihat pada bagan histogram untuk menguji normalitas. Sehingga didapatkan 13 data responden yang harus dibuang. Adapun data responden yang dibuang adalah nomor urut 1, 7, $55,64,109,151,161,183,197,233,235,240$, dan 332. Setelah dibuang ternyata responden yang didapatkan sebanyak 391 orang responden. Berikut ini peneliti sajikan demografi responden.

Tabel 1. Data Demografi Responden

\begin{tabular}{|c|c|c|c|c|}
\hline $\mathbf{o}^{\mathbf{N}}$ & Kriteria & Kategori & $\underset{\text { h }}{\text { Jumla }}$ & $\begin{array}{l}\text { Persentas } \\
\text { e }(\%)\end{array}$ \\
\hline \multirow[t]{2}{*}{1} & \multirow{2}{*}{$\begin{array}{l}\text { Jenis } \\
\text { Kelamin }\end{array}$} & Laki-laki & 159 & 40,7 \\
\hline & & $\begin{array}{ll} & \text { Perempua } \\
\mathrm{n} & \end{array}$ & 232 & 59,3 \\
\hline
\end{tabular}




\begin{tabular}{|c|c|c|c|c|}
\hline \multirow[t]{3}{*}{2} & \multirow[t]{3}{*}{ Usia } & $\begin{array}{l}20 \text { tahun - } \\
30 \text { tahun }\end{array}$ & 260 & 66,5 \\
\hline & & $\begin{array}{l}31 \text { tahun - } \\
40 \text { tahun }\end{array}$ & 98 & 25,1 \\
\hline & & 41 keatas & 33 & 8,4 \\
\hline \multirow[t]{2}{*}{3} & \multirow[t]{2}{*}{$\begin{array}{l}\text { Pendidika } \\
\text { n Terakhir }\end{array}$} & $\begin{array}{lll} & \text { Strata } & 1 \\
(\mathrm{~S} 1) & & \end{array}$ & 221 & 56,5 \\
\hline & & $\begin{array}{lll} & \text { Strata } 2 \\
(\mathrm{~S} 2) & & \\
\end{array}$ & 170 & 43,5 \\
\hline \multirow[t]{5}{*}{4} & \multirow{5}{*}{$\begin{array}{l}\text { Agama } \\
\text { yang dianut }\end{array}$} & Islam & 332 & 84,9 \\
\hline & & Budha & 4 & 1,0 \\
\hline & & Hindu & 7 & 1,8 \\
\hline & & Katolik & 20 & 5,1 \\
\hline & & Kristen & 28 & 7,2 \\
\hline \multirow[t]{2}{*}{5} & \multirow{2}{*}{$\begin{array}{l}\text { Status } \\
\text { Pernikahan }\end{array}$} & Menikah & 170 & 43,5 \\
\hline & & $\begin{array}{l}\text { Belum } \\
\text { Menikah }\end{array}$ & 221 & 56,5 \\
\hline
\end{tabular}

Sumber: Data primer olahan penulis (2021)

Berdasarkan tabel diatas, menggambarkan data responden dari Mahasiswa Pascasarjana Perguruan Tinggi Negeri (PTN) yang terdapat di provinsi DKI Jakarta. Dari data tersebut, tergambarkan bahwasanya jenis kelamin didominasi oleh perempuan sebesar 59,3\% dibandingkan laki-laki hanya sebesar 40,7\%. Usia yang mengisi kuesioner juga didominasi usia muda rentang umur 20 tahun sampai 30 tahun sebesar 66,5\% dan sisanya umur 31 ke atas. Selanjutnya pendidikan terakhir didominasi oleh tamatan S-1 sebesar 56,5\% dan sisanya sebesar 43,5\% berpendidikan S-2. Agama yang dianut rata-rata agama Islam sebesar 84,9\% dikarenakan Indonesia memang mayoritas agama Islam dan terakhir status pernikahan didominasi belum menikah sebesar 56,5\% dan 43,5\% sudah menikah.

Sebelum dilakukan analisis deskripsi dan uji korelasional, peneliti melakukan uji normalitas terlebih dahulu, tujuannya untuk melihat apakah data yang kita teliti itu berdistribusi normal atau tidak. Karena normalitas data ini merupakan persyaratan utama dilakukannya penggujian model korelasional. Untuk lebih jelasnya dapat dilihat pada tabel 2 yang diperoleh dengan menggunakan uji normalitas Kolmogrov-Smirnov Test.

Tabel 2. Uji Normalitas Kolmogrov-Smirnov Test

\begin{tabular}{|c|c|}
\hline Variabel & Nilai Signifikansi \\
\hline Financial Attitude $(F A)$ & 0,137 \\
\hline Financial Knowledge $(F K)$ & 0,093 \\
\hline Spiritual Intelligence $($ SI $)$ & 0,130 \\
\hline
\end{tabular}

Sumber: Data primer olahan penulis (2021) 
Berdasarkan tabel 2, hasil penelitian menunjukkan nilai signifikan sebesar 0,137>0,05, sehingga dapat dikatakan variabel Financial Attitute sudah terdistribusi normal, untuk variabel Financial Knowledge nilai signifikansi 0,093 > 0,05 juga dikatakan terdistribusi normal. Lalu variabel Spiritual Intelligence (X4) memiliki nilai signifikan sebesar 0,130>0,05. Sehingga dapat dikatakan variabel tersebut sudah terdistribusi normal. Setelah memastikan bahwa ketiga data normal, maka peneliti melakukan uji korelasional ketiga variabel. Hasil analisis bisa dilihat pada tabel 3 berikut ini.

Tabel 3. Uji Korelasional Pearson

\begin{tabular}{|r|c|c|c|c|r|}
\hline Variabel & FA & FK & SI & M & SD \\
\hline $\begin{array}{r}\text { Financia } \\
l \text { Attitude }(\text { FA })\end{array}$ & 1 & $.323^{*}$ & .088 & 49.6 & 7.4 \\
\hline $\begin{array}{r}\text { Financia } \\
\text { Knowledge } \\
(\text { FK) }\end{array}$ & $* .323^{*}$ & 1 & $.590^{*}$ & 115. & 7 \\
\hline $\begin{array}{r}\text { Spiritual } \\
\text { Intelligence (SI) }\end{array}$ & .088 & $.590^{*}$ & 1 & 6 & \multicolumn{2}{|c|}{11.} \\
\hline
\end{tabular}

Catatan. M (Rata-rata), SD (Deviasi Standar).

Sumber: Data primer olahan penulis (2021)

Berdasarkan tabel di atas, hasil analisis korelasional menunjukkan bahwa sebagian hubungan bersifat signifikan dan sebagian lagi tidak. Hubungan yang signifikan ditandai dengan simbol bintang dalam skor tersebut. Hubungan yang positif ditandai dengan skor positif pada hasil analisi, bukan negatif. Sementara itu hubungan yang tidak signifikan terjadi pada hubungan FA dengan SI (.088). Untuk hubungan yang signifikan dan positif ditunjukkan oleh hubungan antara FA dengan FK (.323) serta hubungan antara FK dan SI (.590).

Hasil korelasional pada tabel tersebut menunjukkan bahwa terdapat hubungan yang signifikan antara financial attitude dengan financial knowledge. Ini artinya semakin tinggi financial attitude pada seseorang maka akan semakin tinggi pula financial knowledge orang tersebut, begitupun sebaliknya. Selain itu, terdapat hubungan yang signifikan dan positif juga pada financial knowledge dengan spiritual intelligence, ini artinya semakin tinggi financial knowledge seseorang maka akan semakin tinggi pula spiritual intelligencenya, begitupun sebaliknya. Sedangkan untuk analisis antara financial attitude dan spiritual intelligence tidak menunjukkan hubungan yang signifikan, sehingga bisa disimpulkan tidak ada hubungan sama sekali.

\section{Pembahasan}

Berdasarkan hasil penelitian, hubungan yang signifikan antara financial attitude dengan financial knowledge memiliki hubungan yang erat dan saling berdampingan satu sama lain. Ketika seseorang memiliki sikap keuangan yang baik tentu akan berpengaruh langsung kepada pengetahuan keuangannya dan begitu pula sebaliknya. Sikap keuangan itu ditandai dengan 
seseorang yang bisa mengendalikan uang yang dia miliki. Hal ini terlihat ketika memiliki uang dia akan cendrung berbelanja sesuai kebutuhan ketimbang keinginan. Sisa uang ataupun anggaran yang dimilikinya akan ditabung atau disaving untuk kebutuhan masa depan. Sikap seperti ini tentu terkiat dengan ilmu pengetahuan yang sudah diperoleh oleh seseorang. Pengetahuan tersebut mungkin saja tercermin dari tingkah laku yang langsung diimplementasikan dalam kehidupan keseharian mereka.

Secara konseptual sikap keuangan dan pengetahuan keuangan sering kali dijadikan sebagai prediktor atau faktor yang menentukan perilaku manajemen keuangan seseorang. Sehingga beberapa penelitian menyebutkan bahwasanya sikap keuangan dan pengetahuan keuangan memiliki korelasi yang tinggi satu dengan lainnya. Penelitian dari Rizkiawati \& Asandimitra (2018), Asih, Sekar Widi; Khafid (2020), dan Kurniawati (2017) menyatakan variabel sikap keuangan dan pengetahuan keuangan menjadi variabel yang saling berdampingan dan saling berkesinambungan, sehingga tidak bisa dipisahkan satu sama lain. Ketika ada sikap tentu ada ilmu yang diyakini menjadi bagian dari sikap juga.

Walaupun hubungan antara sikap dan pengetahuan itu berhubungan, tetapi peneliti belum menemukan mana yang lebih penting, antara sikap dan pengetahuan terutama dalam pengaruhnya dengan variabel lain. Selanjutnya hasil penelitian lainnya, menunjukkan terdapat hubungan yang signifikan dan positif pada financial knowledge dengan spiritual intelligence. Orang yang memiliki ilmu pengetahuan akan cendrung memiliki spiritual yang bagus dalam kehidupan sehari-harinya. Karena mereka sudah menjalani pendidikan yang begitu lama, baik pendidikan formal maupun pendidikan informal. Seperti halnya, orang yang sudah memiliki titel sarjana ataupun magister tentu akan lebih memiliki pengetahuan yang lebih baik dibandingkan orang yang tidak belajar melalui bangku sekolah. lalu kaitannya dengan kecerdasan spiritual ini terlihat dari agamanya dan kepatuhannya kepada ajaran akan agamanya. Agama tidak hanya mengajarkan hubungan baik secara vertikal dengan Tuhannya, namun mengajarkan hubungan horizontal yang notabenenya melalui pengetahuan.

Selanjutnya karena ini berhubungan dengan pengetahuan keuangan, mau tidak mau juga akan memiliki dampak kepada dalam skala kecil dari pengetahuan luas yang mereka miliki. Dalam studi ini, peneliti juga berasumsi bahwa ketika variabel yang diujikan, yaitu financial attitude, financial knowledge, dan spiritual intelligence berada pada posisi satu yang sama. Padahal kebanyakan penelitian menempatkan variabel sikap keuangan sebagai variabel mediator. Sehingga hubungannya tidak terlalu signifikan dengan kecerdasan spiritual. Hal ini sesuai dengan penelitian dari Akhtar \& Soetjipto (2014). Inilah kekurangan dari penelitian ini, belum ada penelitian sejenis yang memperlihatkan hubungan korelasional dari ketiga variabel tersebut. Financial attitude, financial knowledge, dan spiritual intelligence sebagai variabel yang sama dalam penelitian sebelumnya yaitu diposisi variabel independen. Namun inilah tantangan tersendiri dari penelitian ini. Kedepannya diperlukan riset mendalam supaya bisa terlihat jelas hasil penelitian ini.

\section{KESIMPULAN}


Berdasarkan hasil dan pembahasan ada 3 kesimpulan, pertama terdapat hubungan yang signifikan antara financial attitude dengan financial knowledge pada mahasiswa pascasarjana. Kedua, terdapat hubungan yang signifikan dan positif juga pada financial knowledge dengan spiritual pada mahasiswa pascasarjana. Ketiga, financial attitude dan spiritual intelligence tidak menunjukkan hubungan yang signifikan, sehingga tidak ada hubungan sama sekali pada mahasiswa pascasarjana.

\section{REFERENSI}

Akhtar, H., \& Soetjipto, H. P. (2014). Peran sikap dalam memediasi pengaruh pengetahuan terhadap perilaku minimisasi sampah pada masyarakat terban, Yogyakarta. Jurnal Manusia Dan Lingkungan, 21(3), 386-392.

Akmal, H., \& Saputra, Y. E. K. A. (2016). Analisis tingkat literasi keuangan. Jebi (Jurnal Ekonomi Dan $\quad$ Bisnis 235-244. http://journal.febi.uinib.ac.id/index.php/jebi/article/view/37

Aminatuzzahra. (2014). Persepsi pengaruh pengetahuan keuangan, sikap keuangan, sosial demografi terhadap perilaku keuangan dalam pengambilan keputusan investasi individu (studi kasus pada mahasiswa magister manajemen universitas diponegoro). Jurnal Bisnis Strategi, 23(2), 70-96. https://doi.org/10.14710/jbs.23.2.70-96

Asih, Sekar Widi; Khafid, M. (2020). Pengaruh financial knowledge, financial attitude dan income terhadap personal financial management behavior melalui locus of control sebagai variabel intervening. Economic Education Analysis Journal, 9(3), 748-767 Economic. https://doi.org/10.15294/eeaj.v9i1.42349

Astuti, K. R. (2019). Pengaruh financial knowledge dan income level terhadap financial management behavior dengan locus of control sebagai variabel intervening pada masyarakat kota Makassar. UIN Alauddin Makassar.

Chen, H. \& Volpe, R. P. (1998). An analysis of personal financial literacy among college students. Financial Services Review, 7(2), 107-128.

Chotimah, Chusnul; Rohayati, S. (2015). Pengaruh 2. pendidikan keuangan di keluarga, sosial ekonomi orang tua, pengetahuan keuangan, kecerdasan spiritual, dan teman sebaya terhadap manajemen keuangan pribadi mahasiswa s1 pendidikan akuntansi fakultas ekonomi universitas negeri Surabaya. Jurnal Pendidikan Akuntansi (JPAK), 3(2), 3.

Finance.detik.com. (2020). Ini Tips untuk Para Wanita yang Jadi Menteri Keuangan Keluarga. Https://Finance.Detik.Com/Berita-Ekonomibisnis/d-2384318/Ini-Tips-Untuk-ParaWanita-Yang-Jadi-Menteri-Keuangan-Keluarga.

Furham, A. (1984). Many sides of the coin: the psychology of money usage. Personal and Individual Differences, 5(5), 501-509.

Hidayat, M. M. (2020). Pengaruh literasi keuangan dan kecerdasan spiritual terhadap perilaku pengelolaan keuangan guru sma sederajat dengan locus of control internal sebagai variabel mediasi. STIE Perbanas Surabaya.

Hogarth, J. M. (2002). Financial literacy and family and consumer sciences. Journal of Family 
and Consumer Sciences, 94(1), 15-28.

Humaira, I., \& Sagoro, E. M. (2018). Pengaruh pengetahuan keuangan, sikap keuangan, dan kepribadian terhadap perilaku manajemen keuangan pada pelaku umkm sentra kerajinan batik kabupaten Bantul. Jurnal Nominal, 7(1), 96-110.

Kurniawati, I. D. (2017). Pengaruh sikap terhadap uang dan pengetahuan keuangan dengan mediasi locus of control terhadap perilaku pengelolaan keuangan keluarga. In Artikel Ilmiah Kolaborasi Riset Dosen dan Mahasiswa.

Muson, Carolyne L. J Mason., R. M. S. W. (2000). Conceptualizing Financial Literacy Research Paper 2000:7.

Pankow, D. (2003). Financial values, attitudes, and goals. State University Fargo, North Dakota.

Pasek, N. S. (2016). Pengaruh kecerdasan intelektual pada pemahaman akuntansi dengan kecerdasan emosi dan kecerdasan spiritual sebagai variabel pemoderasi. Jurnal Ilmiah Akuntansi, 1(1), 62-76.

Pradiningtyas, T. E., \& Lukiastuti, F. (2019). Pengaruh pengetahuan keuangan dan sikpa keuangan terhadap locus of control dan perilaku pengelolaan keuangan mahasiswa ekonomi. Jurnal Minds: Manajemen Ide Dan Inspirasi, 6(1), 96. https://doi.org/10.24252/minds.v6i1.9274

Rahmayanti, W., Nuryani, H., \& Salam, A. (2019). Pengaruh sikap keuangan dan perilaku keuangan terhadap literasi keuangan ( studi kasus pada ibu rumah tangga di Desa Lito Kecamatan Moyo Hulu ). Jurnal Manajemen Dan Bisnis, 2(1), 1-9.

Ramadhan, D. A. (2019). Pengaruh pengetahuan keuangan dan kecerdasan spritual terhadap perilaku menabung keluarga muda di Jawa Timur dengan locus of control sebagai variabel mediasi. STIE Perbanas Surabaya.

Ramdani, Z. (2018). Construction of academic integrity scale Implementation School Inclusion View project Psychometric Properties of Psychological Constructs View project Construction of academic integrity scale Construction of academic integrity scale. International Journal of Research Studies in Psychology, 7(1), 87-97. https://doi.org/10.5861/ijrsp.2018.3003

Rasuma Putri, N. M. D., \& Rahyuda, H. (2017). Pengaruh tingkat financial literacy dan faktor sosiodemografi terhadap perilaku keputusan investasi individu. E-Jurnal Ekonomi Dan Bisnis Universitas Udayana, 9, 3407. https://doi.org/10.24843/eeb.2017.v06.i09.p09

Rasyid, R. (2012). Analisis tingkat literasi keuangan mahasiswa program studi manajemen fakultas ekonomi universitas negeri padang. Jurnal Kajian Manajemen Bisnis, 1(2), 32.

Rizkiawati, N. L., \& Asandimitra, N. (2018). Pengaruh demografi, financial knowledge, financial attitude, locus of control dan financial self-efficacy terhadap financial management behavior masyarakat Surabaya. Jurnal Ilmu Manajemen (JIM), 6(3), 2. https://jurnalmahasiswa.unesa.ac.id/index.php/jim/article/view/23846/21793

Sina, P. G. dan A. N. (2012). Pengaruh kecerdasan spiritual terhadap pengelolaan keuangan pribadi. Jurnal Manajemen, 11(2).

Sugiyono. (2017). Metode penelitian kuantitatif, kualitatif, dan $R \& D$ (26th ed.). Alfabeta. 
Suharsimi, A. (2010). Prosedur penelitian suatu pendekatan praktik. Rineka Cipta.

Sunar, D. (2010). Edisi lengkap tes iq, eq, dan sq (cara mudah mengenali dan memaknai kepribadian). Flash Books.

Sunyoto, D. (2013). Teori, kuesioner \& analisis data untuk pemasaran dan perilaku konsumen. Graha Ilmu.

Triwidisari, A., Ahmad, N., \& M. (2017). The relationships between instagram social media usage, hedonic shopping motives and financial literacy on impulse buying. Jurnal Dinamika Pendidikan, 12(2), 170-181.

Yamauchi, K.T, Templer, D. . (1982). The development of money attitude scale. Journal of Personality Assesment, 5(46), 522-528.

Zohar, D., \& Marshall, I. (2007). SQ-Kecerdasan Spiritual. Mizan Pustaka. 